\title{
Müzik Dersinde Çevrilmiş Öğrenmeye İlişkin Bir Ölçek Geliştirme Çalışması ${ }^{1}$
}

\begin{tabular}{lccc}
\hline MAKALE TÜRÜ & Başvuru Tarihi & Kabul Tarihi & Erken Görünüm Tarihi \\
Araştırma Makalesi & 17.11 .2017 & 13.03 .2018 & 13.03 .2018 \\
\hline
\end{tabular}

\author{
Salim Sever (iD ${ }^{2}$ \\ Ankara Üniversitesi \\ Gülşah Sever iD ${ }^{3}$ \\ Gazi Üniversitesi
}

\begin{abstract}
Öz
Bu çalışmanın amacı çevrilmiş öğrenme modeliyle yapılan müzik derslerine ilişkin görüş ve algıları tespit etmek üzere bir ölçek geliştirmektir. Bu amaçla oluşturulan deneysel form uzmanlara sunulmuş ve dönütler doğrultusunda maddelerin kapsam geçerlik oranı belirlenmiș ve .40 'ın altında değer alan maddeler çalışma kapsamı dışında bırakılmıştır. Oluşturulan 23 maddelik deneme formu 141 öğrenci üzerinde uygulanmış, elde edilen veriler analiz edilmiş ve 12 maddelik bir yapıya ulaşılmıştır. Açımlayıcı Faktör Analizi (AFA) ile "Bilgi", "Farkındalık" ve "Beceri" olmak üzere üç boyutlu ve toplam 12 maddeden oluşan bu yapının alt ölçekleri arasındaki ilişkiye bakılmış ve faktörlerin birbirleriyle pozitif ve anlamlı ilişki içinde oldukları görülmüştür. Alt boyutların müzikte çevrilmiş öğrenme modeli algısını ortaya koyan bileșenler olduğu ve birlikte bir üst yapıyı oluşturduğu görülmüștür. Ölçeğin tümü için elde edilen iç tutarlılık katsayısı ise .80 olarak belirlenmiştir. Müzik dersinde çevrilmiş öğrenmeye ilişkin geçerli ve güvenilir bir ölçek geliştirilmiştir.
\end{abstract}

Anahtar sözcükler: Müzik Eğitimi, Çevrilmiş Öğrenme, Sınıf Eğitimi, Okul Öncesi Eğitimi, Ölçek Geliştirme

\footnotetext{
1 Bu makale Ankara Ünivesitesi BAP kapsamında yapılan 15 B0630002 no'lu projenin verileri kullanılarak üretilmiştir.

2 Sorumlu Yazar: Doç. Dr., Eğitim Bilimleri Fakültesi, Temel Eğitim Bölümü, E-posta: sever@ankara.edu.tr, https://orcid.org/0000-0003-4028-4514

Arş. Gör. Dr., Gazi Eğitim Fakültesi, Güzel Sanatlar Eğitimi Bölümü, E-posta: gulsah.sever@gmail.com,http://orchid.org/0000-0003-0559-6993
} 
Okul öncesi ve ilkokul döneminde gerçekleştirilen müzik etkinlikleri çocuğun sosyal, duygusal, zihinsel ve fiziksel gelişimine önemli katkılar sağlar. Mantie ve Tucker $(2008,224)$ okulda öğrenilen temel müzikal eğitimin "tüm yaşamın en değerli hazzı" olduğuna ilişkin genel bir inanışın olduğunu belirtirler. Kreutz $(2008,1)$ müziğin özellikle çocukların düşünmelerinde ve hissetmelerinde etkili olduğunu, Fiske (1999) ise müzik eğitimi alan bireylerin sadece bu alanda değil, başka alanlarda da başarı gösterdiklerini vurgular. Lamont (1998) yapmış olduğu araştırma sonucunda müzik eğitiminin okuma ve matematik başarısına katkı yaptığı bulgusuna ulaşmıştır. Standley (1996), 98 araştırmayı kapsayan yaptığı meta analiz çalışmasında müziğin, çocuklar ve yetişkinler üzerinde okul içindeki ve dışındaki öğrenme ve davranış gelişimlerinde oldukça önemli olduğunu ortaya koymuştur. Müzik etkinlikleri yoluyla öğrencilerin edindiği kazanımları da Vries (2004) motor becerilerin gelişmesi, sosyalleşme, kendini ifade etme ve dinleme becerilerinin gelişmesi biçiminde sıralamaktadır. Temel eğitim çağındaki çocuklar için bu derece önemli olan müzik eğitiminin gerçekleştirilebilmesi için okul öncesi ve sınıf öğretmenlerinin müziği temel düzeyde bilmeleri ve bunun için de bir enstrüman çalabilmeleri gerekmektedir. Bu eğitimin lisans düzeyinde etkili bir biçimde yapılabilmesi özellikle günün teknolojik imkânlarından faydalanabilmeyi gerektirmektedir.

Teknoloji ve iletişim alanlarında 19. yüzyılın başından itibaren meydana gelen gelişmelerin etkisiyle eğitimde de var olan paradigmalar değișmekte ve giderek artan bir hızda yeni öğrenme-öğretme yaklaşımları ve sınıf modelleri oluşturulmaktadır. Bu modellerden biri de çevrilmiş öğrenme ya da çevrilmiş sınıf modelidir. Çevrilmiş öğrenme modelinin oluşumunda teknoloji kullanımının yanı sıra öğrenme amaçlarına uygunluk da gözetilmektedir.

Bloom (1956) ve Anderson ve Krathwohl (2001)'a göre öğrenme çeşitli basamaklardan oluşmaktadır. $\mathrm{Bu}$ basamaklar bilişsel alanda bilgi, kavrama, uygulama, analiz, sentez, değerlendirme iken duyușsal alanda alma, tepkide bulunma, değer verme, örgütleme, niteleme ve psikomotor alanda da algilama, kurulum, kılavuzla yapma, mekanikleşme, beceri haline getirme, uyum ve yaratma basamaklarıdır.

Geleneksel sınıf eğitimi sisteminde öğretmen çoğunlukla bilgi ve kavrama basamaklarına ilişkin bilgileri sınıf içinde öğrencilere aktarır. Çevrilmiş öğrenme modelinde ise bu basamaklara ilişkin bilgiler önceden hazırlanmış çalışma kâğıtları, videolar, görseller vb. gibi materyaller ile ders öncesinde öğrencilere ulaştırılır. Öğrenciler alt düzey bilgileri teknoloji aracılığıyla sınıf dışında edinirken, sınıfta öğretmen ve sınıf arkadaşları ile üst düzey düşünme becerilerini kullanır (Herreid ve Schiller, 2013). Sınıfta geçirilen zaman problem çözme ve pratik uygulamalar gibi aktif öğrenmelere ayrılır (Bergmann ve Sams, 2012). Buradaki temel amaç yüz yüze eğitimin niteliğini arttırmaktır (Bergmann ve Sams, 2014; Milman, 2012).

Çevrilmiş sınıf modeli öğrenen-öğrenci, öğrenen-öğretmen arasındaki etkileşimi arttırır, öğretmenlerin öğrencilerin bireysel gereksinimlerini dikkate 
almalarını sağlar (Bergmann ve Sams, 2012). Çevrilmiş Öğrenme, öğrencilerin bireysel öğrenme hızına ve gereksinimlerine odaklanır. Pearson Okul Başarısı Servisi (2013) ve Flipped Learning çalışma grubu bu gereksinimleri karşılamanın yolu olarak esnek öğrenme ortamları oluşturulması, öğrenme kültürünün değişsimi amaçlı bir içerik oluşturulması ve eğitimin uzman kişilerce verilmesi olmak üzere dört temel yapı taşı belirlemiştir (McKnight, McKnight ve Arfstrom, 2013).

Çevrilmiş öğrenme modeli başta tıp ve mühendislik alanlarında olmak üzere birçok alanda uygulanmaktadır (Pierce ve Fox, 2012; Tune, Sturek ve Basile, 2013; Pearson, 2012; Lento, 2016). Ancak dünyada ve Türkiye'de müzik eğitimi alanındaki uygulamalar henüz sınırlı sayıdadır (Grant, 2013; Sever, 2014; Sever ve Sever, 2017). Ülkemizde eğitim fakültelerinde okul öncesi eğitimi programlarında haftalık müzik dersi 3. sınıfın ilk döneminde üç saat, ikinci yarıyılda ise haftalık dört saattir. Sınıf eğitimi programında ise 2. sınıfta yıl boyunca üç saattir. Bu süre her iki program bakımından da öğretmen adaylarının hem müziğe ilişkin temel kavramları öğrenmesi hem enstrüman çalabilmesi hem de öğretmenlik hayatlarında müzik etkinliklerini düzenleme bakımından gerekli donanıma sahip olmaları için yeterli olamamaktadır. Zira ders, kuramsal bilginin beceriye dönüştürülmesini gerektirmektedir ki geniş zamanlarda kuramsal bilginin sindirilebilmesi bu sürecin ayrılmaz bir parçasıdır. Bu gereksinimi karşılamak ve eğitimin niteliğini artırmak amacıyla çevrilmiş öğrenme uygulaması yapılmıştır. Bu sayede kuramsal bilgi, çalışma/ uygulama yönerge ve teknikleri ders öncesi zamana alınarak sınıf içi zaman, performans becerilerine ve etkinlik oluşturma çalışmalarına ayrılabilmiştir.

Her sınıf modelinde öğrenme alanına, uygulama şekline, uygulayıcılara ve öğrencilere bağlı olarak farklı sonuçlar alınabilir. Uygulamanın işleyen ve geliştirilmesi gereken yönlerini belirlemek için çevrilmiş sınıf modeli ve tasarlanan öğretim videoları hakkında dönüte gereksinim duyulmuştur. $\mathrm{Bu}$ bağlamda araştırmanın amacı, çevrilmiş öğrenme modeline ilişkin uygulamalar hakkındaki görüşlerin alınacağı ve nasıl algılandığının saptanabileceği bir ölçek geliştirmek olarak belirlenmiştir.

\section{Yöntem}

$\mathrm{Bu}$ çalışma, çevrilmiş öğrenme modeliyle yapılan müzik derslerine ilişkin görüş ve algıları tespit etmek üzere bir ölçek geliştirme çalışması olarak kurgulanmıştır. "Çevrilmiş öğrenme görüş ölçeği” geliştirme çalışmasının aşamaları ve çalışma grubunun özellikleri aşağıda sunulmuştur.

\section{Çalıșma Grubu}

$\mathrm{Bu}$ araştırmanın çalışma grubunu 2015-2016 eğitim öğretim yılında Ankara Üniversitesi Eğitim Bilimleri Fakültesi Temel Eğitim Bölümü Sınıf Eğitimi ve Okul Öncesi Eğitimi programlarında kayıtlı, müzik dersi alan lisans 2. ve 3. sınıf öğrencileri oluşturmaktadır $(n=141)$. Öğrencilerin müzik derslerinde bir öğretim yılı boyunca çevrilmiş öğrenme yaklaşımına uygun olarak hazırlanmış bir müzik eğitimi programı uygulanmıştır. Öğrenciler ölçek geliştirme sürecine gönüllü olarak 
katılmışlardır. Çalışmaya katılan öğrenciler, lisans dönemi öncesinde örgün eğitim dışında müzik dersi almamış ve piyano çalma deneyimi yaşamamış bireylerdir. Temel müzik bilgisine (notaların süre ve isimleri, bona, solfej, temel düzeyde enstrüman çalma) sahip öğrenci bulunmamaktadır.

\section{Video Derslerinin Hazırlanması}

$\mathrm{Bu}$ araştırmada ele alınan konu, müzik eğitimi ve performans olduğundan öğrencilere görsel-işitsel bilgi sunulması ihtiyacı doğmuştur. Bu nedenle çevrilmiş öğrenme modeli uygulama süreci, araştırmacılar tarafından tasarlanan videolar kullanılarak yapılmıştır.Videolar, oluşturulan Google mail grubu üzerinden link ve gerekli çalışma materyali gönderilerek bir hafta öncesinden öğrencilere ulaştırılmıştır. Böylece öğrencilerin derse hazırlanarak gelmeleri sağlanmıştır.

Eğitsel video hazırlığında video stratejisi belirlemek, öncelikle küçük ölçekli videolardan başlamak, konuyu ilgi çekici ve etkileşimli bir biçimde sunmak önemlidir (Raths, 2014). Janz, Graetz ve Kjorlien (2012) ve McKnight vd. (2013)'ne göre, hazırlanacak videonun her açıdan iyi planlanması gereklidir. İyi planlanmış bir video, bilişsel yük getirecek gereksiz bilgilere yer verilmeyen, konunun mümkün olduğunca kısa ve anlaşılır olarak ifade edildiği, çelişkilere yer vermeyecek materyalin kullanıldığı bir tasarım olarak tanımlanabilir.

$\mathrm{Bu}$ araștırmada kullanılan videoların hazırlanmasında öncelikle içerik planlaması yapılmıştır. Seçilen parçalar, parçalar içinde yer alan müzik ve psikomotor becerilere ilişkin kavramlar analiz edilerek parçalarda yer alan kuramsal konular ve uygulama için önemli görevler belirlenmiştir. Bu konu ve görevlerin öğretim basamakları kolaydan zora, basitten karmaşı̆̆a sıralanmıştır. Sıralanan öğretim basamaklarının video çekimi için planlanması gereği duyularak videonun hangi dakikasında hangi görüntünün, konunun ve konuşmanın yer alacağına ilişkin bir çizelge hazırlanmıştır. Video süreleri 3-8 dakika arasında sınırlandırılmıştır. Hazırlanan 11 eğitim videosunun toplam süresi 58 dakikadır. Videolar içerikleri ve zorluk dereceleri göz önünde bulundurulup sıralanarak öğrencilere iletilmiştir.

\section{Uygulama}

Müzikle ilgili temel bilgiler ve düzeye göre kuramsal bilgileri de içeren şarkıların piyano ile çalınmasına yönelik olarak hazırlanmış olan eğitim videoları bir hafta öncesinden "Flip Learner" adlı youtube kanalına yüklenerek e-posta grubu yoluyla video linki ve ilgili evrak öğrencilere iletilmiştir. Öğrenciler derslere bu videolara çalışarak gelmişlerdir. Sınıf içi uygulama içerisinde öğrencilere ısınmak ve parçaları hatırlamak için süre tanınmıştır. Bu süre boyunca öğrencilerin birbirlerini rahatsız etmeden çalışabilmesi için kulaklık kullanmaları sağlanmıştır. Aynı zamanda öğrencilere proje ekibince bireysel zaman ayırılarak parçaların eksik veya yanlış çalışılmış kısımları hakkında dönüt verilmiştir. Bu sırada öğrencilerin de birbirleriyle etkileşimini artırmak amacıyla grup çalışmaları yapılmasına özen gösterilmiştir. Benzer bir etkileşim daha iyi çalabilen bazı öğrencilerin de kendi arkadaşlarına yardım etme çabası göstermesi ile de ortaya çıkmıştır. Bu çalışma ve 
hatırlama sürecinden sonra öncelikle istekli öğrencilerden başlamak üzere her öğrenci teker teker performansını çalma ve dinletme firsatı bulmuştur. Performanslar uzman görüşleri de alınarak hazırlanan bir derecelendirilmiş puanlama anahtarı (DPA) yoluyla değerlendirilmiştir. Aynı DPA ile öğrencilerin kendilerini de değerlendirmeleri istenmiş, bu yolla performans kriterlerine ve kendi performanslarına ilişkin farkındalıklarının da artması amaçlanmıştır. Her öğrenciye bireysel zaman tanınmış ve öğrencilere birbirlerinin performanslarından da öğrenme firsatı sunulmuştur. $\mathrm{Bu}$ sayede sınıf içi etkileşimin ve öğrenme düzeyinin yükseltilmesi sağlanmıştır.

\section{Ölçeğin Geliştirilmesi}

Ölçeğin hazırlık aşamasında ilk olarak alanyazın incelenmiş ve öğrencilerin derse yaklaşımına ilişkin benzerlikler saptanarak uygulamanın boyutları ortaya konulmaya çalışılmıştır. Bunlar, çevrilmiş öğrenme ile ilgili genel değerlendirme (Bilgi), kendi hızında çalışma (Farkındalık) ve performans değerlendirmesi (Beceri) olmak üzere üç başlık olarak belirlenmiştir. Her bir alt boyutu kapsayacak şekilde 35 sorudan oluşan bir havuz oluşturulmuştur. Birinci boyut için 15 , ikinci boyut için 10 ve üçüncü boyut için de 10 soru hazırlanmıştır.

Dil, anlatım ve ifadelerin uygunluğu bakımından üçü müzik, biri Türkçe ve biri ölçme alanlarından olmak üzere beş uzmanın görüşü alınmıştır. Uzmanların görüşlerinin alınabilmesi için 3'lü derecelendirme kullanılmıştır. Formdaki her bir madde için "uygun", "kısmen uygun" ve "uygun değil" seçeneklerinden birini işaretlemeleri beklenmiştir. Müzik alanı uzmanlarından alınan formların tümü tek bir forma aktarılarak her bir maddenin olası seçeneklerine kaç uzman tarafından onay verildiği saptanmıştır. Maddelerin kapsam geçerliği Veneziano ve Hooper (1997; akt. Yurdagül, 2005) tarafindan geliştirilen kapsam geçerlik oranı ile belirlenmiş, buna göre olumlu yanıt veren uzman sayısı, toplam uzman sayısına oranlanmış ve çıkan sayının bir eksiği olarak saptanmıştır. Maddelerin kapsam geçerlilik indeksleri için de uzman sayıları ve kapsam geçerlik oranlarının değerleri belirlenmiş, 0.40'ın altında kalan maddeler kapsam dışı bırakılmıştır (Comrey ve Lee, 1992). Bu hesaplamalar doğrultusunda bazı maddeler çıkartılmış, bazı maddelerdeki ifadeler ise düzeltilmiştir. Ardından 23 maddelik bir deneme formu oluşturulmuştur. Katılımcılardan "Tamamen Katılıyorum”, "Katılıyorum”, "Kısmen Katılıyorum", "Katılmıyorum", "Kesinlikle Katılmıyorum” ifadelerini içeren 5'li Likert tipi bir ölçek üzerinde kendi görüşlerini belirtmeleri istenmiştir. Likert-tipi sorular araştırılan konu hakkında tutum veya görüş içeren bir ifade ve bu ifadeye katılım düzeyini belirten seçenekler içerir. Likert-tipi sorularda katılım düzeyini belirlemek amacıyla iki aşırı uç arasında yer alan birden çok seçenek sunulur. Bu seçenekler "en yüksekten en düşüğe" veya "en iyiden en kötüye" doğru dereceli bir şekilde sıralanır (Turan, Şimşek ve Arslan, 2015). 


\section{Verilerin Toplanması ve Analizi}

Ölçek çalışması Ankara Üniversitesi Eğitim Bilimleri Fakültesi Sınıf Öğretmenliği ve Okul Öncesi Öğretmenliği programlarında müzik dersi alan öğrenciler üzerinde 2016-2017 öğretim yılı içerisinde uygulanmıştır. Öğrencilerden her bir ifadeye ilişkin görüşlerini 1-5 arasında puanlamaları istenmiştir. Buna göre 1Kesinlikle Katılmıyorum, 2-Katılmıyorum, 3-Kararsızım, 4-Katılıyorum ve 5Kesinlikle Katılıyorum şeklinde gruplanarak değerlendirmeye alınmıştır. Ölçekte yer alan beş negatif madde ters çevrilerek kodlanmıştır.

İlk aşamada 23 madde olarak hazırlanan ölçek, öğrenci gurubuna $(\mathrm{N}=141)$ uygulanmıştır. Araştırmaya katılan 141 öğrenciden alınan yanıtlar doğrultusunda ölçeğin geçerlik güvenirlik çalışmaları yapılmıştır. Analiz sonucunda Faktör analizi için gerekli örneklem büyüklüğü incelenmiş ve çalışma grubu yeterli görülmüştür (Büyüköztürk, 2002; Tabachnick ve Fidell, 2001). Ölçeğin yap1 geçerliğini belirlemek için varimax döndürme ile temel bileşenler analizi kullanılarak Açımlayıcı Faktör Analizi (AFA) yapılmıştır. Analizde faktör yükleri en az .40 olarak belirlenmiştir (Büyüköztürk, 2006). Güvenirlik için Cronbach Alfa hesaplanmış ve ölçeğin güvenilir kabul edilebilmesi için, Cronbach Alfa $(\alpha)$ katsayısının değerlendirilmesinde ise şu ölçütler esas alınmıştır: $0.00 \leq \alpha<0.40$ ise ölçek güvenilir değildir, $0.40 \leq \alpha<0.60$ ise ölçek düşük güvenirliktedir, $0.60 \leq \alpha<0.80$ ise ölçek oldukça güvenilirdir, $0.80 \leq \alpha<1.00$ ise ölçek yüksek derecede güvenilirdir (Özdamar, 2002, 673).

\section{Bulgular ve Yorum}

Bu bölümde "Çevrilmiş öğrenme görüş ölçeği” geliştirme çalışmasının geçerlik ve güvenirlik çalışmalarına ilişkin bulgulara yer verilmiştir.

\section{Geçerliğe İlişkin Bulgular}

Ölçeğin yapı geçerliğini ortaya koymak ve maddelerin faktör yüklerini belirleyerek boyutlandırabilmek amacıyla faktör analizi yapılmıştır. Faktör analizine başlamadan önce verilerin faktör analizine uygunluğunu saptamak üzere KaiserMeyer-Olkin (KMO) katsayısı ve Barlett Sphericity testi hesaplanmıştır. Veriler küçük bir gruptan ve araştırmacının kontrolünde toplandığından katılımcılar samimiyetle ve eksiksiz bir şekilde ölçeği cevaplandırmışlardır. Bu sebeple de veri setinde kayıp veri ve uç değerler bulunmamaktadır. Bu hesaplamalar sonucunda KMO değeri .823 bulunmuş ve Bartlett testi sonucu da $(557,566 \mathrm{p}<0.001)$ anlamlı çıkmıştır (George ve Mallery, 2001). Comrey ve Lee (1992)'nin yaklaşımları esas alınarak hiç bir faktörde yüklenmeyen ve madde faktör yükü .40'1n altında olan 11 madde analizden çıkartılmıştır. Faktör sayısı alanyazın dikkate alınarak ve çalışmanın amacı kapsamında üç olarak kabul edilmiştir.

Analiz sonucunda 6 faktör ortaya çıkmıştır. Faktör yükü olmayan veya birden fazla faktörde yakın yük değeri alan maddeler çıkartılmıştır. Ancak 5. ve 6 . faktörlerde yalnızca birer soru yer aldığı için bu faktörler de değerlendirmeye 
alınmamıştır. Çıkartılan soruların korelasyonlara ve faktör yüklerine olan etkisini test etmek amacıyla faktör analizi yinelenmiştir. Yapılan faktör analizi sonucunda 12 madde elde kalmış ve bu maddeler açıklama gücüne sahip üç faktörde toplanmıştır. Bu faktörler ve her bir faktör altında toplanan maddeler ve faktör yükleri Tablo 1'de verilmiştir.

Tablo 1

Maddeler ve Faktör Yükleri

\begin{tabular}{|c|c|c|c|c|}
\hline Faktörler & Maddeler & \multicolumn{3}{|c|}{ Faktör Yükleri } \\
\hline \multirow{8}{*}{ Bilgi } & 1. Video dersleri aktif öğrenmeyi destekler. & \multicolumn{3}{|l|}{.82} \\
\hline & $\begin{array}{l}\text { 2. Video dersleri öğrenmeyi daha ulaşılır hale } \\
\text { getirir. }\end{array}$ & \multicolumn{3}{|l|}{.80} \\
\hline & 3. Videolu öğretim yaklaşımı, öğretmen & \multirow{3}{*}{\multicolumn{3}{|c|}{.79}} \\
\hline & odaklı geleneksel yaklaşıma kıyasla derse & & & \\
\hline & Kat1l1m oranını artırır. & & & \\
\hline & $\begin{array}{l}\text { 4. Videolu uygulama süresince kendi } \\
\text { öğrenme tempomu kolaylıkla belirledim. }\end{array}$ & \multicolumn{3}{|l|}{.74} \\
\hline & $\begin{array}{l}\text { 5. Video izlemek yerine geleneksel bir } \\
\text { öğretmeni izlemeyi tercih ederim. }\end{array}$ & \multicolumn{3}{|l|}{.73} \\
\hline & $\begin{array}{l}\text { 6. Videolu öğretim yaklaşımını kimseye } \\
\text { tavsiye etmem. }\end{array}$ & \multicolumn{3}{|l|}{.71} \\
\hline \multirow{3}{*}{ Farkındalık } & $\begin{array}{l}\text { 1. Kendi ögrenme hızımda çalışmaktan } \\
\text { hoşlanmam. }\end{array}$ & \multicolumn{3}{|c|}{.79} \\
\hline & $\begin{array}{l}\text { 2. Kendi öğrenme-çalışma tempomu } \\
\text { belirlemekten hoşlanmadım. }\end{array}$ & \multicolumn{3}{|c|}{.66} \\
\hline & $\begin{array}{l}\text { 3. Videolu yaklaşım sınıf içi çalışmalar için } \\
\text { az zaman bıraktı. }\end{array}$ & \multicolumn{3}{|c|}{.49} \\
\hline \multirow{3}{*}{ Beceri } & $\begin{array}{l}\text { 1. Video dersleri piyano çalmak dışındaki } \\
\text { kuramsal müzik bilgilerini de öğrenmemi } \\
\text { sağladı. }\end{array}$ & \multicolumn{3}{|r|}{.78} \\
\hline & $\begin{array}{l}\text { 2. Kendi performansımı değerlendirmek } \\
\text { öğrenme sürecimi olumlu etkiler. }\end{array}$ & & & .76 \\
\hline & $\begin{array}{l}\text { 3. Performansıma dönüt verilmesi öğrenme } \\
\text { niteliğini artırır. }\end{array}$ & & & .68 \\
\hline \multicolumn{2}{|l|}{ Öz Değer } & 4.42 & 1.43 & 1.11 \\
\hline \multicolumn{2}{|c|}{ Açıklanan Varyans (\%) } & 36.82 & 11.94 & 9.22 \\
\hline
\end{tabular}

AFA sonucunda ölçeğin özdeğerinin 1 'den büyük 3 faktör altında toplandığ görülmüştür. Bu üç faktörün açıkladığı toplam varyans ise \% 57.98 dir.

Tablo 1'de açımlayıcı faktör analizine ait faktör yükleri verilmiştir. Birinci boyut faktör yükü .71 ile .82 aralığında değișen 6 maddeden oluşmaktadır. İkinci boyut faktör yükü .49 ile .79 arasında değişen 3 maddeden oluşmaktadır. Üçüncü boyut faktör yükü ise .68 ile .78 arasında değişen 3 maddeden oluşmaktadır. Tüm faktörlerin toplam varyansın \% 57.98'ini açıkladığı görülmüştür. Birinci faktör 
toplam varyansın \% 36.8'ini açıklamakta olup çevrilmiş öğrenmede video kullanımına ilişkin genel yaklaşımı belirten ifadelerden oluşmaktadır ve video etkisi (Bilgi) olarak adlandırılmıştır. İkinci faktör toplam varyansın \% 12.0 'ını açıklamakta olup kendi hızında çalışabilme durumuna ilişkin ifadelerden oluşmaktadır ve "Farkındalık" olarak adlandırılmıştır. Üçüncü faktör ise toplam varyansın \% 9.2'sini açıklamakta olup performans değerlendirmesine ilişkin ifadelerden oluşmaktadır ve "Beceri" olarak adlandırılmıştır. Analiz sonuçlarına göre işleyen tüm maddelerin planlanan boyutları yansıttığı görülmüştür. Yapılan analizlerde ölçeğin alt ölçekleri arasındaki ilişkiye de bakılmıştır. Faktörler arasındaki korelasyon katsayıları Tablo 2'de sunulmuştur.

Tablo 2

Faktörler Arasındaki Korelasyon Katsayıları

\begin{tabular}{lccc}
\hline Faktör & $\mathbf{1}$ & $\mathbf{2}$ & $\mathbf{3}$ \\
\hline 1 & 1.00 & & \\
2 & .18 & 1.00 & \\
3 & .37 & .03 & 1.00 \\
\hline
\end{tabular}

Analiz sonucunda faktörlerin birbirleriyle pozitif ve anlamlı $(\mathrm{p}<0.001)$ ilişki içinde olduğu görülmüştür.

\section{Güvenirliğe İlişkin Bulgular}

$\mathrm{Bu}$ ölçeğin 12 maddesinin güvenirliği için Cronbach Alfa iç tutarlılık katsayısı hesaplanmıştır. Her bir alt boyut ve ölçeğin tümü için elde edilen Cronbach Alfa katsayıları Tablo 3'te verilmiștir.

Tablo 3

Madde Sayılart ve Cronbach Alfa Katsayıları

\begin{tabular}{lcc}
\hline & Madde sayısı & Cronbach Alfa \\
\hline 1. Bilgi & 6 & 0.86 \\
2. Farkındalık & 3 & 0.41 \\
3. Beceri & 3 & 0.62 \\
Ölçeğin Tümü & 12 & 0.80 \\
\hline
\end{tabular}

Tablo 3'teki güvenirlik değerleri incelendiğinde "Bilgi" alt boyutu için iç tutarlılık katsayısının .86, "Farkındalık" alt boyutu için .41, "Beceri" alt boyutu için .62 olduğu görülmektedir. Ölçeğin tümü için elde edilen iç tutarlılık katsayısı ise .80 'dir. Ölçeğin "Farkındalık" alt boyutu için elde edilen güvenirlik katsayısı her ne kadar düşük çıkmıșsa da diğer alt boyutlar ve ölçeğin tümü üzerinden elde edilen değerlerin yeterli olduğunu söylemek mümkündür. $\mathrm{Bu}$ nedenle elde edilen değerlerin bu ölçeğin müzik eğitiminde çevrilmiş öğrenme uygulamasına ilişkin algıların ölçülmesi için güvenilir bir araç olduğunu gösterdiği söylenebilir. 


\section{Sonuç ve Öneriler}

$\mathrm{Bu}$ çalışmada çevrilmiş öğrenme uygulamasına ilişkin algıları saptamak amacıyla bilgi, farkındalık ve beceri alt boyutlarından oluşan 12 maddelik bir ölçek geliștirilmiştir. Ölçeğin KMO değeri .823 bulunmuş ve Bartlett testi sonucu da $(557,566 \mathrm{p}<0.001)$ anlamlı çıkmıştır. Açımlayıcı faktör analizine ait faktör yükleri birinci boyut için .71 ile .82 aralığında değişen 6 maddeden oluşmaktadır. İkinci boyut faktör yükü .49 ile .79 arasında değişen 3 maddeden oluşmaktadır. Üçüncü boyut faktör yükü ise .68 ile .78 arasında değişen 3 maddeden oluşmaktadır. Tüm faktörlerin toplam varyansın \% 57.98'ini açıkladığı görülmüştür. Ölçeğin alt boyutlarına ilişkin elde edilen Cronbach Alfa katsayıları $(\mathrm{Bilgi}=.86$, Farkındalık $=$ .41 , Beceri $=.61$ ) alt boyutlarda yer alan maddelerin birbirleriyle tutarlı olduğunu göstermektedir. Bu araştırmanın sonucunda ölçeğin yeterli psikometrik özeliklere sahip olduğu görülmüştür. Farkındalık alt boyutunun .41 düzeyinde görece düşük çıkmasının bu alt boyutta yer alan maddelerin sayıca az olmasından kaynaklanmış olabileceği düşünülmektedir. $\mathrm{Bu}$ durumun bir pratik sinırlılık olarak okuyucu tarafindan dikkate alınması beklenmektedir.

Bu araştırma yalnızca Ankara Üniversitesi Eğitim Bilimleri Fakültesinde Sınıf Öğretmenliği ve Okul Öncesi Öğretmenliği programlarına kayıtll, müzik dersi alan öğrencilerle gerçekleştirilen müzik eğitiminde çevrilmiş öğrenme uygulamasını içeren bir proje kapsamında gerçekleştirilmiştir. Türkiye'de bu tür bir yaklaşımla eğitim almış veya almakta olan, doğrulayıcı faktör analizi (DFA) uygulanabilecek bir başka öğrenci grubu bulunmadığından sadece açımlayıcı faktör analizi (AFA) yapılabilmiştir. Bu durumun da çalışmaya ilişkin pratik bir sınırlılık olarak okuyucu tarafindan dikkate alınması beklenmekte ve ileride yapılacak olan çalışmalarda DFA yapılması önerilmektedir. Buna ek olarak ileride daha büyük gruplarla yapılacak çalışmalarda test tekrar test, ölçme değişmezliği ve madde yanlılığına ilişkin testlerin de yapılması önerilmektedir.

Eğitim fakültelerinde verilen müzik eğitiminin gelişmesi okul öncesi öğretmeni ve sınıf öğretmeni olma yolundaki öğrencilerin meslek yaşamlarında müzikal donanıma sahip öğretmenler olarak yer almalarına olanak sağlayacaktır. Çevrilmiş öğrenme algı ölçeğinin, müzik eğitimi alanındaki çevrilmiş öğrenme uygulamalarını teşvik edecek ve çevrilmiş öğrenme modeli ile yapılan diğer çalışmaların planlanıp geliştirilmesine katkı yapacak bir araç olduğu düşünülmektedir. Bu bakımdan müzik eğitiminin mesleki bir amaçla yapıldığı lisans programlarının tümünde çevrilmiş öğrenme uygulamalarına yer verilmesi önerilmektedir. 


\section{Kaynakça}

Anderson, L. W., and Krathwohl, D. R. (Eds.). (2001). A taxonomy for learning, teaching and assessing: A revision of Bloom's taxonomy of educational objectives: Complete edition, New York: Longman.

Bergmann, J., and Sams, A. (2012). Flip your classroom: Reach every student in every class every day. International Society for Technology in Education. Washington: Iste.

Bergmann, J., and Sams, A. (2014). Flipped learning: Maximizing face time. T+DJournal, 68(2), 28-31.

Bloom, B. S. (ed.)(1956). Taxonomy of Educational Objectives. Vol. 1: Cognitive Domain. New York: McKay.

Büyüköztürk, Ş. (2002). Faktör Analizi: Temel Kavramlar ve Ölçek Geliştirmede Kullanım1. Kuram ve Uygulamada Ĕgitim Yönetimi, 32, 470-482.

Comrey, A. L., and Lee, H. B. (1992). A first course in factor analysis ( $2^{\text {nd }}$ ed.). Hillsdale, NJ: Erlbaum.

deVries, P. (2004). The Extramusical Effects of Music Lessons o Preschoolers, Australian Journal of Early Childhood, 29(2), 6-10.

Grant, C. (2013). First inversion: A rationale for implementing the "flipped approach" in tertiary music courses. Australian Journal of Music Education, 1, $3-12$.

Herreid, C., and Schiller, N. (2013). Case Studies and the Flipped Classroom. Journal of College Science Teaching, 42, 62-66.

Janz, K., Graetz, K., and Kjorlien, C. (2012). Building collaborative technology learning enviroments. SIGUCCS '12 Conference, Memphis, Tennessee, USA.

Kreutz, G., Schubert, E. and Mitchell, Laura A. (2008), Cognitive Styles of Music Listening, Music Perception: An Interdisciplinary Journal, 26(1), 57-73, University of California Press.

Lamont, A. (1998). Music, Education and the development of pitch perception: the role of context, age, and musical experience. Psychology of Music, 26(1), 7-25.

Lento, C. (2016). Promoting active learning in introductory financial accounting through the flipped classroom design. Journal of Applied Research in Higher Education 8(1), 72-87.

Mantie, R., and Tucker, L. (2008). Closing the gap: Does music making have to stop upon graduation? International Journal of Community Music, 1, 217-227.

McKnight P., McKnight, K., and Arfstrom, K. (2013). A review of flipped learning. Flipped Learning Network. 
Milman, N. (2012) The flipped classroom strategy: What is it and how can it be used? Distance Learning, 9(3), 85-87.

Özdamar, K. (2002). Paket Programlar ile İstatistiksel Veri Analizi. 4. Basım, Eskişehir: Kaan Kitabevi.

Pearson, G. (2012) Biology teacher's Flipped Classroom: ‘A simple thing, but it's so powerful'. Education Canada, 52(5).

Pierce, R. and Fox, J. (2012). Vodcasts and Active-Learning Exercises in a "Flipped Classroom" Model of a Renal Pharmacotherapy Module. American Journal of Pharmaceutical Education: 76(10), 196.

Raths, D. (2014). Nine video tips for a better flipped classroom. Education Digest, 79(6), 15-21.

Sever, S. ve Sever. G. (2017). Students'self-Assessments Regarding The Effects of Flip Learning Practice In Music Lessons. Electronic Turkish Studies 12(18), 20.

Standley, J.M. (1996). A meta-analysis onthe effects of music as reinforcement for education/therapy objectives. Journal of Research in Music Education, 44, 105-133.

Tabachnick, B.G. and Fidell, L. S. (2001). Using multivariate statistics (4th Ed). Needham Heights: Allyn \& Bacon.

Tune, J. D. Sturek, M. Basile, D. P. (2013). Flipped classroom model improves graduate student performance in cardiovascular, respiratory, and renal physiology. Advances in Physiology Education: 37, 4.

Turan, İ , Şimşek, Ü , Aslan, H . (2015). Eğitim Araştırmalarında Likert Ölçeği ve Likert-Tipi Soruların Kullanımı ve Analizi. Sakarya Üniversitesi Eğitim Fakültesi Dergisi, (30), 186-203.

Yurdagül, H. (2005). Ölçek Geliştirme Çalışmalarında Kapsam Geçerlik İndeksinin Kullanımı. 14. Eğitim Bilimleri Kongresi, Pamukkale Üniversitesi, Denizli. 
Ankara University Journal of Faculty of Educational Sciences

Year: 2018, Volume: 51, Issue: 1, 105-117

DOI:10.30964/auebfd.405036, E-ISSN: 2458-8342, P-ISSN: 1301-8342

\title{
A Scale Development Study Related to Flipped Learning in Music Lesson ${ }^{1}$
}

\begin{tabular}{lccc}
\hline ARTICLE TYPE & Received Date & Accepted Date & Online First Date \\
Research Article & 11.17 .2017 & 03.13 .2018 & 03.14 .2018 \\
\hline
\end{tabular}

Salim Sever (iD) ${ }^{2}$

Ankara University

\section{Gülşah Sever (iD) ${ }^{3}$ \\ Gazi University}

\begin{abstract}
The purpose of the study is to develop a scale to determine the opinions and perceptions 2ndand 3rd grade pre-school and elemantary school teacher candidates on flipped learning model that was applied in music lessons. With this aim, in order to get their opinions the draft form was sent to experts, item content validity ratios were determined and items below .40 valued were eliminated. 23 item draft form was administered to 141 students, and the data were analysed. Through, explanatory factor analysis (EFA), a constuct with 23 items and 3 factors, named "Knowledge", "Awareness", and "Skill" was achieved. The relationship among sub scales was tested and a significant positive relationship was found. The Cronbach's Alpha value for the scale was found to be .80 .
\end{abstract}

Keywords: Music education, flipped learning, elementary education, preschool education, scale development

\footnotetext{
${ }^{1}$ Supported by the Ankara University, Scientific Research Fund BAP Project No. 15B0630002

${ }^{2}$ Corresponding Author: Assoc. Prof., Faculty of Education, Department of Elementary Education, Email: sever@ankara.edu.tr, https://orcid.org/0000-0003-4028-4514

3 Res. Asst. Dr., Faculty of Education, Department of Fine Arts Education, E-mail: gulsah.sever@gmail.com, http://orchid.org/0000-0003-0559-6993
} 


\section{Summary}

\section{Purpose and Significance}

The purpose of the study is to develop a scale to determine the opinions and perceptions of teacher candidates flipped learning model that was applied in music lessons.

\section{Method}

With a study group consist of $1412^{\text {nd }}$ and $3^{\text {rd }}$ grade students, flipped learning model was applied on music lessons. Scenarios of the video lessons were prepared on the basis of cognitive task analysis through an ascending level from basic to advanced skills. The videos were uploaded to flip learner youtube channel and posted to the studens. The classtime was divided into two sections that students could practice and perform. Scale was developed in that process. In order to get their opinions the draft form was sent to experts, item content validity ratios were determined and items below .40 valued were eliminated .23 item draft form was administered to 141 students, and the data were analysed.

\section{Results}

Through, explanatory factor analysis (EFA), a constuct with 23 items and 3 factors, named "Knowledge", "Awareness", and "Skill" was achieved.The relationship among sub scales was tested and a significant positive relationship was found. The Cronbach's Alpha value for the scale was found to be .80 .

\section{Discussion and Conclusions}

The scale was found to be useful and qualified in terms of a psychometric evaluation. 